\title{
School climate and peer victimization: perceptions of students with intellectual disability
}

\author{
Clima escolar e vitimização entre pares: percepções de estudantes com \\ deficiência intelectual
}

\section{Clima escolar y victimización entre pares: percepciones de los estudiantes con discapacidad intelectual}

\author{
Hellen Tsuruda Amaral \\ Professor PhD student at State University of Paraná, Paranavaí, PR, Brazil \\ E-mail: hellentsuruda@gmail.com ORCID: https://orcid.org/0000-0003-4511-4426 \\ Josafá Moreira da Cunha \\ PhD Professor at the Federal University of Paraná, Curitiba, PR, Brazil \\ E-mail: josafas@gmail.com ORCID: https://orcid.org/0000-0002-4003-6847 \\ lasmin Zanchi Boueri \\ Post-doctoral professor at the Federal University of Paraná, Curitiba, PR, Brazil \\ E-mail: boueri.iasmin@gmail.com ORCID: https://orcid.org/0000-0002-7398-1992 \\ Jonathan Bruce Santo \\ Professor of University of Nebraska Omaha, Omaha, NE, United States of America \\ E-mail: jsanto@unomaha.edu ORCID: https://orcid.org/0000-0002-2057-1519
}

Received on August 27th, 2020

Approved on February $3^{\text {rd }}$, 2021

Published on February $16^{\text {th }}, 2021$

\section{ABSTRACT}

Considering the experiences of students with intellectual disabilities (ID) in educational environments, peer victimization stands out for potential losses to development. This is a relationship problem, which requires an understanding of contextual factors. In the approach of the authoritative school climate, the perception of support and disciplinary structure act as possible attenuators of peer victimization. However, the association between school climate and victimization is rarely examined in samples with people with ID. Thus, the study aimed to examine the associations between authoritative school climate and peer victimization through a procedure accessible to the self-report of people with ID. It was hypothesized that the disciplinary structure and support would be negatively associated with victimization. The study included 117 students with ID, aged between 12 and 63 years (mean $=25.31$; $s d=12.25$ ); $62.4 \%$ of male participants; $56.9 \%$ white and $54.1 \%$ diagnosed with moderate $\mathrm{DI}$. The measures and procedures went through a cognitive accessibility process to enable the participation of students with ID through self-report, the data were analyzed using structural equation modeling. The adaptation was partially successful. In the final model, the disciplinary structure was positively correlated to support, which was a negative predictor for victimization. The results highlight how school environments with a 
supportive school climate can be a protective factor in relation to the victimization of people with ID, and that more inclusive practices in scientific research are possible.

Keywords: authoritative school climate; people with intellectual disability; peer victimization.

\section{RESUMO}

Considerando as experiências de estudantes com deficiência intelectual (DI) em ambientes educacionais, a vitimização entre pares se destaca por potenciais prejuízos para o desenvolvimento. Este é um problema de relacionamento, que demanda a compreensão de fatores do contexto. Na abordagem do clima escolar autoritativo, a percepção de suporte e estrutura disciplinar atuam como possíveis atenuadores da vitimização entre pares. Entretanto, a associação entre o clima escolar e a vitimização raramente é examinada em amostras com pessoas com DI. Assim, o estudo teve por objetivo examinar as associações entre o clima escolar autoritativo e a vitimização entre pares por meio de procedimento acessível para o autorrelato de pessoas com DI. Hipotetizou-se que a estrutura disciplinar e o suporte estariam associados negativamente à vitimização. O estudo incluiu 117 estudantes com DI, com idade entre 12 e 63 anos (média= 25,31; d.p.=12,25); 62,4\% dos participantes do sexo masculino; 56,9\% brancos e 54,1\% com diagnóstico de DI moderada. As medidas e procedimentos passaram por processo de acessibilidade cognitiva para possibilitar a participação dos estudantes com DI por meio do autorrelato, os dados foram analisados usando a modelagem de equações estruturais. O processo foi parcialmente bem-sucedido. No modelo final, a estrutura disciplinar foi positivamente correlacionada ao suporte, que foi um preditor negativo para a vitimização. Os resultados destacam como os ambientes escolares com um clima escolar de suporte podem ser um fator protetor em relação à vitimização de pessoas com DI, e que práticas mais inclusivas na pesquisa científica são possíveis.

Palavras-chave: clima escolar autoritativo; pessoas com deficiência intelectual; vitimização entre pares.

\section{RESUMEN}

Considerando las experiencias de estudiantes con discapacidad intelectual (DI) en los entornos educativos, la victimización entre iguales se destaca por posibles pérdidas para el desarrollo. Este es un problema de relación, que requiere una comprensión contextual. En el abordaje del clima escolar autoritativo, la percepción de soporte y estructura disciplinaria actúan como posibles atenuadores de la victimización entre iguales. Pero, la asociación entre el clima escolar y la victimización rara vez se examina en personas con DI. Así, el estudio tuvo como objetivo examinar las asociaciones entre el clima escolar autoritativo y la victimización por iguales por medio de un procedimiento accesible para el autoinforme de personas con DI. Se hipotetizó que la estructura disciplinaria y el apoyo se asociarían negativamente con la victimización. El estudio incluyó 117 estudiantes con DI, con edad entre 12 y 63 años (media = 25,31; d.e. = 12,25); el 62,4\% de los participantes eran del sexo masculino; el $56,9 \%$ eran blancos y el $54,1 \%$ con DI moderada. Las medidas y procedimientos pasaron por un proceso de accesibilidad cognitiva para posibilitar la participación de estudiantes con DI mediante autorrelato, los datos fueron analizados 
usando un modelaje de ecuaciones estructurales. La adaptación fue parcialmente exitosa. En el modelo final, la estructura disciplinaria fue positivamente correlacionada con el soporte; un predictor negativo para la victimización. Los resultados destacan los ambientes escolares con un clima acogedor pueden ser factor protector en relación a la victimización de personas con $\mathrm{DI}$, cuya inclusión en la investigación científica es posible.

Palabras clave: clima escolar autoritativo; persona con discapacidad intelectual; victimización entre pares

\section{Introduction}

The education of students with intellectual disability continues to challenge educational systems worldwide, offering avenues for inclusion and positive academic and social experiences within and outside of the school context. And although issues such as peer victimization and school climate have received an increasing scrutiny in the literature in the last thirty years (LA SALLE et al., 2018; WILLIFORD et al., 2019) research examining these issues through the lenses of students with intellectual disabilities is still sparse (AMARAL, 2018). Therefore, the present study explores the association between peer victimization and school climate though the self-report of students with intellectual disability.

The education of people with disabilities in Brazil underwent transformations through several decades, moving from segregation towards inclusive approaches to schooling, expressed by the intention of quality education to all students, regardless of their individual characteristics (MONTEIRO; RIBEIRO, 2019; SANTOS; MARTINS, 2015). Positive experiences in schools can play a fundamental role in the positive development of people with disabilities (WEHMEYER, 2013), with broad societal impacts (OLIVEIRA et al., 2012; MAÏANO et al., 2016).

Peer victimization stands out as a form of violence that is often found in the school environment and can be defined as experiences of being targeted by harmful actions from peers (CUNHA, 2012). This relational processes are linked with individual and contextual aspects (HONG; ESPELAGE, 2012) and, non-surprisingly, the characteristics of the school context can play a positive role and reduce the risk for peer victimization (KONOLD et al., 2017; PEDRO et al., 2016), and there is a growing literature examining such influences through the lenses of the school climate (AMARAL; CUNHA; SANTO, 2019; THAPA et al., 2013), through which the contextual influences of the characteristics and experiences on academic settings can be studied systematically (LENZ; ROCHA; ARAS, 2020). The school climate reflects the quality of relations in schools, such as rules, objectives, teaching practices, 
http://dx.doi.org/10.5902/1984686X53606

safety, and school environment organization (COHEN et al., 2009). Aspects of the school environment such as safety and inclusion, respect for diversity and rules that are clear and fair have been linked to a number of positive outcomes (HOLST et al., 2016; THAPA et al., 2013) such as improved academic functioning (BERKOWITZ et al., 2017), in addition to preventing emotional problems (ALDRIDGE; MCCHESNEY, 2018) and risk behaviors such as peer victimization (EUGENE; DU; KIM, 2021; VINHA et al., 2016).

A persistent challenge for the school climate literature is to find a systematic definition for the construct (RAMSEY et al., 2016). The school climate can be broadly defined through the lenses of the authoritative school climate theory (KONOLD; CORNELL, 2015), focused on the study of the main and interactive influences of the school's support and disciplinary structure (BEAR; YANG; PASIPANODYA, 2015; STOCKARD; MAYBERRY, 1992). While support is focused on how well the school responds to the students (and other members) needs for caring and supportive environments, the disciplinary structure refers to the fair and consistent implementation of rules in the school. This theory is related to Diana Baumrind's parenting styles theory (BAUMRIND, 1966) and provides a parsimonious and consistent approach to the study of the influences of the school climate.

The main effects and the interaction between disciplinary structure and support have been linked to positive outcomes, both at the student level (MAXWELL et al., 2017) and also at the school level (LÅFTMAN; ÖSTBERG; MODIN, 2017). Previous research indicates that environments with authoritative school climates have lower rates of peer victimization (AMARAL; CUNHA; SANTO, 2019; BERG; CORNELL, 2016), and are generally associated with a school perceived by students as welcoming and safe (FISHER et al., 2018), positive student-teacher relations and higher reports of acceptance of rules in school (BERG; CORNELL, 2016). This theory points out that schools should work towards enhancing both a fair disciplinary structure and the quality of relations between teachers, other professionals and students (CORNELL; HUANG, 2016). Moreover, aspects of the school environment can also make a difference when students are exposed to violence, such as buffering the ill effects of victimization towards minority students (ALEXANDER et al., 2011; MOYANO; SÁNCHEZFUENTES, 2020). Unfortunately, despite advancements in inclusive policies in schools, research on school climate still has a gap regarding the experiences of students with ID, who are seldom included or identified in school climate studies (AMARAL, 2018).

Although the literature on peer victimization continues to expand (ARAÚJO; COUTINHO, 2020; COELHO, 2016; JOSEPH; STOCKTON, 2018; KRETSCHMER, 2016), 
http://dx.doi.org/10.5902/1984686X53606

specific reports that take into account the experiences and perceptions of students with disabilities are less common (AMARAL, 2018). Aspects of the school climate, such as supportive student-teacher relations, can attenuate the impact of hostile interactions in the school environment (PINA; ARAUJO, 2014). The quality of relations of students with disability with their peers can enhance the behavioral adjustment of said students (WIENER, 2004), and one could argue that an authoritative school climate creates an inclusive context, which both prevents behavioral problems such as peer victimization and is also conducive to learning and positive development of students with disabilities.

Research indicates a global tendency of greater involvement of people with disabilities into violence situations than their peers without disabilities (EMERICH; ALCKMINCARVALHO; MELO, 2017; MAÏANO et al., 2016; MUSIL et al., 2014). It is noteworthy that reports of violence involving students with disabilities may be biased due to the challenge of adapting measures and procedures to study the experiences and perceptions of people with disabilities. For example the students with disabilities may be simply removed from the study in the sampling procedures (WILLIFORD et al., 2019), or may not be given the opportunity to provide responses directly (e.g.,BEAR; YANG; PASIPANODYA, 2015), which may provide a biased perspective regarding the experiences of these participants. Usually in those cases, teachers or parents provide information about the student's experiences into school.

Fortunately, there are methodological responses to enhance research accessibility for people with disabilities, including people with intellectual disabilities (ID), so that they can provide self-reports about aspects such as life quality (BREDEMEIER et al., 2014) and their work environments (ALVES; DA SILVA, 2020). Such efforts indicate that it is possible to engage participants with intellectual disabilities in research that relies on self-reports, given the necessary accessibility tools. This could represent a change specially in larger sample studies, which usually do not take this in account. Given this background, this study seeks to advance the procedures and measures that enable people with intellectual disability to engage as research participants in a more direct manner, through measures cognitively accessible to participants and based on universal design (OLIVEIRA; NUNES, 2018; OLIVEIRA et al., 2013; THOMPSON; JOHNSTONE; THURLOW, 2002).

\section{The present study}

Although the association between the components of an authoritative school climate have been established as predictors of lower levels of peer victimization (AMARAL; CUNHA; 
SANTO, 2019; BERG; CORNELL, 2016; KONOLD; CORNELL, 2015), this association is yet to be studied in a sample of people with intellectual disabilities. Thus, the present study seeks to examine how an authoritative school climate can predict lower levels of peer victimization among students with intellectual disability. The study examines how aspects of an authoritative school climate, including support and disciplinary structure, predict lower levels of peer victimization among students with intellectual disability. It also seeks to provide a nuanced perspective to the study of these issues by assessing school climate and peer victimization through accessible measures and procedures, thus enhancing research participation accessibility.

First, it was hypothesized that the authoritative school climate would be organized in a two level hierarchy, with the latent factors of disciplinary structure and support being predicted by an authoritative school climate (BERG; CORNELL, 2016; THAPA et al., 2013), while peer victimization would be aggregated in a single latent factor. Secondly, it was hypothesized that the school's disciplinary structure and support would be negatively associated with peer victimization (BERG; CORNELL, 2016; CORNELL; SHUKLA; KONOLD, 2015; KONOLD; CORNELL, 2015), above and beyond the influence of age or gender of participants.

\section{Methodology}

\section{Participants}

Participants were 117 students from four public special education schools in the Metropolitan Area of the city of Curitiba, Brazil, selected by convenience. Although national policies for education in Brazil require that students with a disability should be preferably enrolled in regular schools (BRASIL, 2015), the State of Parana, where the research was conducted has policies that maintain a large proportion of students with disabilities in segregated special schools (PARANÁ, 2009; PARANÁ, 2013). In 2017, about 48\% of students with disabilities were registered in special classes, mostly in special schools (TODOS PELA EDUCAÇÃO, 2017). Although the participants were selected by convenience, this could be a step to understand the quality of relations into this type of school, that is quite common in the province of the conducted research.

The participants were aged between 12 and 63 years (Mage=25.31; SD=12.25). Thus, the sample was composed by adolescents and adults, with $62.4 \%$ of participants self- 
http://dx.doi.org/10.5902/1984686X53606

reported as males, $34.9 \%$ as females and $2.7 \%$ did not know how to answer to the question about their sex. The racial profile of the sample was assessed through the Brazilian Census categories (LOVEMAN; MUNIZ; BAILEY, 2012) in addition to an open ended option, and $56.9 \%$ self-identified as white (branco), $12.9 \%$ as black (preto ou pardo), $14.7 \%$ as asian (amarelo), and $11.9 \%$ with other identifications, such as brown (marrom) and $15.5 \%$ did not know how to answer the item about their racial identification.

The enrollment of the students in these special schools was based on a prior diagnostic of intellectual disability provided by schools, since the information about diagnostic procedures or reports used in the student's enrollment was not available to researchers. The school report on the student's diagnosis of intellectual disability was obtained, including $10.7 \%$ with a mild ID, $54.1 \%$ moderate, $2.5 \%$ severe and $32.7 \%$ with non-specified ID.

\section{Measures}

\section{Universal Design Perspective}

This process was driven by the universal design perspective, in order to promote human rights and inclusion in all aspects of research and evaluation. The universal design perspective is guided by the principle that an evaluation should be accessible in order to accommodate the specific needs of participants while maintaining valid scientific inferences (OLIVEIRA; NUNES, 2018; OLIVEIRA et al., 2013; THOMPSON; JOHNSTONE; THURLOW, 2002). In this paper, the focus in universal design is regarding an assessment tool for school climate and victimization. However, the universal design is used in other areas, such as education - universal design for learning, a rising approach into educational settings ((BOCK; GESSER; NUERNBERG, 2018). Allied with the universal design approach, cognitive accessibility was also an important issue in this study. Cognitive accessibility can be described as the way people can comprehend their environment and its information (LEÓNA; LEÓN-LÓPEZ, 2019). Therefore, something can be considered cognitively accessible when someone can apprehend its meaning. In this study, the original measures were modified in search of a universal design, which needs also to be cognitively accessible to all people.

The key elements of this approach are the understanding of the target population's accessibility needs, having well-defined constructs, the use of accessible items and instructions (OLIVEIRA; NUNES, 2018; THOMPSON; JOHNSTONE; THURLOW, 2002), while the guidelines of the Federal Board of Psychologists guidelines for the adaptation of 
http://dx.doi.org/10.5902/1984686X53606

instruments (CONSELHO FEDERAL DE PSICOLOGIA, 2013) also informed the accessibility procedures. Steps for modification included the selection of the instruments for hypothesis testing based on the literature; inclusion of an Acquiescence and Discriminative Test (ADT), described in the procedures; item's adjustment and reduction to three points of response (never, sometimes, always), in order to maximize the comprehension of the scales, based on recommendations from previous studies with ID participants (CANTORANI; PILATTI; GUTIERREZ, 2015; SCHMIDT et al., 2010). The fourth stage involved the evaluation of the new version of the scales by experts on ID studies, and last the approved changes were implemented for testing of the modified version of the scale.

Following these initial stages, a pilot study was conducted to evaluate the instrument modification with nine students with ID (mild diagnostic $44.5 \%$, moderate $33.3 \%$, severe $11.1 \%$ and non-specified $11.1 \%$ ), including $77.8 \%$ male, between 20 and 40 years old (Mage $=27.8, S D=6.3$ ). The data collection occurred individually in the school, and time to complete the questionnaire ranged between 15-30 minutes, and eight of the students requested that the researchers read the forms for them. The items that were not easily understood by participants were reviewed, with the inclusion of an alternative explanation to be used whenever the item was not accessible to the student (e.g., Item: DC3: "Quando eu e meus colegas fazemos algo errado, nós podemos explicar" - "When my colleagues and I do something wrong, we can explain", if the participant does not understand, researcher says "Quando brigam com alguém, podem falar por que ficaram brabos" When they fight with someone, they can talk about why they got angry "). The participants of the pilot study were again consulted by the researchers and presented fewer doubts during the application of the scales, resulting in the modified versions of the instruments described below.

\section{Authoritative School Climate Scale - Modified Version (ASCS-MV)}

Authoritative School Climate was evaluated through a modified version of the Authoritative School Climate Scale (CUNHA; AMARAL; MACEDO, 2019; KONOLD; CORNELL, 2015). Considering the characteristics of the sample, the scale was changed for a cognitively more accessible version following the procedures described above.

This is a self-report instrument that examines the perception of the school climate considering the disciplinary structure (composed by seven items; e.g.: "The school rules 
http://dx.doi.org/10.5902/1984686X53606

are fair") and support (eight items; e.g., "Most teachers and other adults at this school care about all students"). Table 1 presents items and their respective means and standard deviations in the present study. As this was the first study to use this version of the scale, also in a novel population, the factorial structure of the scale was tested, and more details are provided in the results section.

Table 1 - Items, Portuguese description, mean, standard deviation of the Authoritative School Climate Scale - Modified Version (ASCS-MV) - Final Model

\begin{tabular}{|c|c|c|c|c|}
\hline ITEM & DESCRIPTION & MEAN & DP & RANGE \\
\hline DC3 & $\begin{array}{l}\text { TRATAM OS ESTUDANTES COM RESPEITO, } \\
\text { NÃO IMPORTA A COR DA PELE } \\
\text { EX.: Se houver alunos, por exemplo, da etnia } \\
\text { branca e preta na sala: } \\
\text { "Tratam os alunos brancos e pretos com respeito" }\end{array}$ & 1.58 & 0.72 & $0-2$ \\
\hline$D C 6$ & $\begin{array}{l}\text { EU CONCORDO COM AS REGRAS DA } \\
\text { ESCOLA. Ex. O aplicador deve usar exemplos da } \\
\text { realidade do aluno: "é certo fazer as tarefas"; "é } \\
\text { certo não bater nos amigos"; "é certo pedir para ir } \\
\text { no banheiro", caso essas sejam regras da escola. }\end{array}$ & 1.63 & 0.68 & $0-2$ \\
\hline$D C 7$ & $\begin{array}{l}\text { QUANDO EU E MEUS COLEGAS FAZEMOS } \\
\text { ALGO ERRADO, NÓS PODEMOS EXPLICAR. } \\
\text { Ex.: Quando brigam com alguém, podem falar por } \\
\text { que ficaram brabos }\end{array}$ & 1.32 & 0.77 & $0-2$ \\
\hline$S P 1$ & $\begin{array}{c}\text { EU E MEUS COLEGAS SOMOS CUIDADOS } \\
\text { PELOS PROFESSORES E OS OUTROS } \\
\text { ADULTOS DA ESCOLA }\end{array}$ & 1.78 & 0.50 & $0-2$ \\
\hline$S P 2$ & $\begin{array}{l}\text { OS PROFESSORES E OS OUTROS ADULTOS } \\
\text { DA ESCOLA QUEREM QUE EU E MEUS } \\
\text { COLEGAS FAÇAM BEM AS ATIVIDADES. EX.: } \\
\text { Os professores querem que os alunos vão bem } \\
\text { nas provas e nas tarefas }\end{array}$ & 1.86 & 0.42 & $0-2$ \\
\hline SP4 & $\begin{array}{l}\text { EU E MEUS COLEGAS SOMOS TRATADOS } \\
\text { PELOS PROFESSORES E OS ADULTOS DA } \\
\text { ESCOLA COM RESPEITO. EX. Os } \\
\text { professores/adultos da escola tratam bem os } \\
\text { alunos }\end{array}$ & 1.79 & 0.47 & $0-2$ \\
\hline SP8 & $\begin{array}{c}\text { QUANDO EU FAÇO MINHAS TAREFAS TEM UM } \\
\text { PROFESSOR OU OUTRO ADULTO NA ESCOLA } \\
\text { QUE FICA MUITO FELIZ }\end{array}$ & 1.83 & 0.49 & $0-2$ \\
\hline
\end{tabular}

Note: The alternative explanations were only provided when students did not understand an item.

Source: Data from the present study (2017). 
http://dx.doi.org/10.5902/1984686X53606

\section{Peer Victimization Scale - Modified Version (PVS-MV)}

Peer victimization was evaluated through a modified version of the Aggression and Victimization Scale (CUNHA; WEBER; STEINER, 2011), following the same procedures described earlier. This is also a self-report instrument that investigates peer victimization through direct aggression, relational aggression and victimization (composed by eight items, e.g., "Colleagues hurt me"). In this study, only victimization was tested and the items are represented at table 2 .

Table 2 - Items, Portuguese description, mean, standard deviation of the Peer Victimization Scale - Modified Version (PVS-MV) - Final Model

\begin{tabular}{|c|c|c|c|c|}
\hline ITEM & DESCRIPTION & MEAN & DP & RANGE \\
\hline VIT2 & $\begin{array}{c}\text { OS COLEGAS ME BATERAM OU CHUTARAM } \\
\text { Ex.: Os colegas me bateram, chutaram, deram um } \\
\text { soco, empurraram }\end{array}$ & 0.34 & 0.67 & $0-2$ \\
\hline VIT3 & $\begin{array}{c}\text { OS COLEGAS FALARAM QUE IAM ME BATER, } \\
\text { MACHUCAR, BRIGAR COMIGO } \\
\text { Ex.: Falaram: "vou te bater"; "vou te chutar"; "você } \\
\text { vai ver só!" }\end{array}$ & 0.31 & 0.59 & $0-2$ \\
\hline VIT4 & $\begin{array}{c}\text { OS COLEGAS MEXERAM NAS MINHAS } \\
\text { COISAS SEM EU DEIXAR OU PEGARAM } \\
\text { COISAS MINHAS SEM PEDIR } \\
\text { Ex. Pegaram minha mochila ou outra coisa sem } \\
\text { eu deixar. }\end{array}$ & 0.48 & 0.77 & $0-2$ \\
\hline VIT6 & $\begin{array}{c}\text { COLEGAS ME DEIXARAM DE FORA DA } \\
\text { CONVERSA/BRINCADEIRA } \\
\text { Ex.: Os colegas não me deixaram conversar ou } \\
\text { brincar com eles }\end{array}$ & 0.49 & 0.78 & $0-2$ \\
\hline
\end{tabular}

Note: The alternative explanations were only provided when students did not understand an item.

Source: Data from the present study (2017).

\section{Procedures}

\section{Data Collection}

This project is part of a larger study called: "Peer victimization: individual and schools contexts factors", which was conducted after the approval from the Ethics Review Board (ERB) from the Federal University of Paraná (UFPR). About the specific procedures which 
provided the data for this analysis, it was funded by the Coordenação de Aperfeiçoamento de Pessoal de Nível Superior (CAPES).

Following the process of adaptation of the instruments, four schools were contacted and provided authorization for the implementation of the study. An informed consent form was sent to the legal guardians of the participants, and oral assent was also obtained from the participants prior to the study. The forms for participants were programmed in the software KoBoToolbox (CORCINO; CUNHA, 2017), which allowed the data to be safely collected through the use of electronic forms in tablets. This type of data collection enabled students with physical disabilities to participate more easily, as they could navigate and select the desired answers on the screen of the tablet. Participants who could not read by themselves or presented doubts during data collection were assisted by the research team ( $n=93.2 \%)$.

\section{Acquiescence and Discriminative Test (ADT)}

The use of self-reports by participants with disabilities has been the subject of growing scrutiny in the literature (BREDEMEIER et al., 2014). Given the characteristics of participants, as an initial stage of the study, the Acquiescence and Discriminative Test - ADT (BOUERI et al, 2015) was used. This test is composed of two steps acquiescence and discrimination, to examine whether the participant with ID understands the instructions and questions used in a self-report questionnaire and provides information to researchers.

The first step is focused on acquiescence, which examines the ability to understand questions from a personal perspective. In order to implement the acquiescence test, it is necessary to acquire prior information from someone who knows the participant for at least six months. Considering the being school-based characteristic of the study, teachers provided the initial information. Next, in the acquiescence stage the teachers provided researchers with four questions to be proposed for the students (e.g., Question: Do I live in your home with you?; Expected answer: No). The questions should be framed for simple affirmative or negative responses, including two for each type of response. In order to adhere to each participant's context, there was no model for questions, only for the type of answer (i.e., yes or no).

Next, in the discriminative step, the teachers indicated three questions regarding everyday activities that their students executed. Their expected answers should include three options following the type of questions of the study: "always", "sometimes", "never" (e.g., Question: Do you wear a school uniform in school?; Expected answer: Always). 
http://dx.doi.org/10.5902/1984686X53606

After the information provided by teachers, the research team performed the ADT with the participants, with seven questions. The ADT was used as a way to researchers to understand the answers of the participants, especially those who used alternative communication - and to be sure if the participant understood the type of question in the forms. Given the objectives for this study, the ADT was not a inclusion or exclusion criteria for participation, but a complementary instrument to enable the data collection.

\section{Analysis Plan}

\section{Authoritative School Climate}

The research hypothesis was tested using a structural model equation - path analysis - implemented through the Mplus software 6.0 (MUTHÉN; MUTHÉN, 2010). Figure 1 presents the hypothesized model.

Figure 1 - Hypothetical model

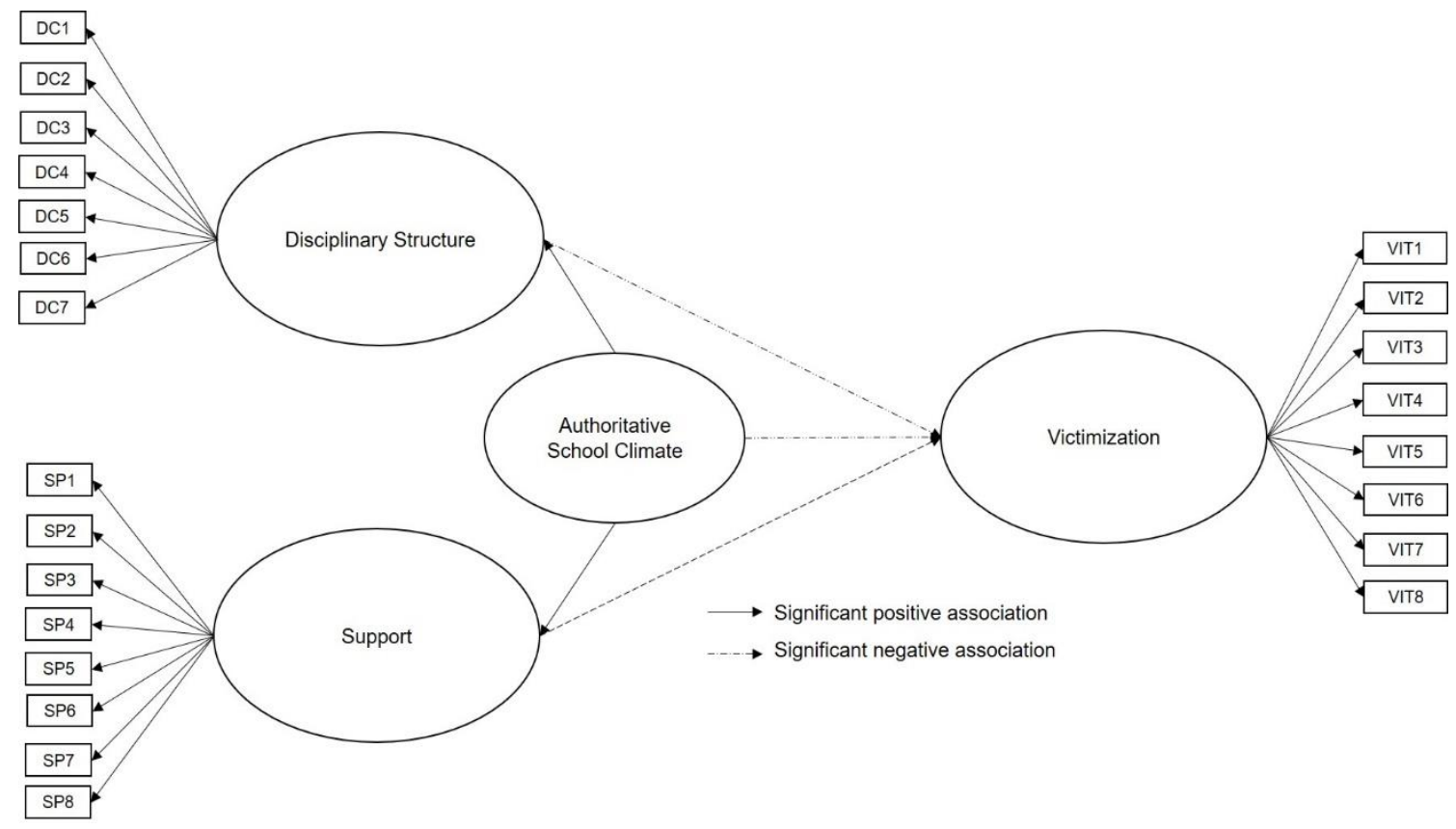

Source: Figure developed by the authors (2017).

Model began by latent constructs of authoritative school climate: disciplinary structure and support. Both dimensions of school climate were inserted in the model as predictors for peer victimization. Gender and age were added as control variables.

The parameters adopted for statistically acceptable models were (KLINE, 2011): nonsignificant chi-square $(X 2)$ changes between models; comparative fit index $(\mathrm{CFI})$ above .9; 
root mean square error of approximation (RMSEA) equal or below .06; standardized root mean square residual (SRMR) below de .08. Additionally, scale items with lower loadings on the latent factors were removed for alternative model construction. The internal consistency of measures was assessed through Cronbach's alpha (CRONBACH, 1951), and criteria equal or above .6 (GEORGE; MALLERY, 2003) was used to analyze the reliability for the proposed dimensions.

Table 3 presents the internal consistency results, number of items, mean, standard deviation, and variables of the final model of the study.

Table 3 -Cronbach's Alpha, Number of items, means, standard deviation, and range of final model

\begin{tabular}{c|c|c|c|c|c|c}
\hline DIMENSION & CRONBACH'S ALPHA & $\begin{array}{c}\text { NUMBER } \\
\text { OF ITEMS }\end{array}$ & $\mathbf{n}$ & MEAN & SD & RANGE \\
\hline $\begin{array}{c}\text { Disciplinary } \\
\text { Structure }\end{array}$ & 0.54 & 3 & 117 & 1.55 & 0.68 & $0-2$ \\
\hline Support & 0.80 & 4 & 117 & 1.78 & 0.42 & $0-2$ \\
\hline Victimization & 0.82 & 4 & 117 & 0.47 & 0.60 & $0-2$ \\
\hline
\end{tabular}

Source: Data from the present study (2017).

\section{Results}

\section{Correlational analyses}

Disciplinary structure and support were positively correlated, indicating that both dimensions of school climate were related in the study. Victimization was negatively associated with support, which can indicate an association between a supportive school perceived by the student and lower self-reports of victimization. No other significant correlations were found (see table 4).

Table 4 - Correlation among the variables of the study

\begin{tabular}{c|c|c|c}
\hline DIMENSION & $\mathbf{1}$ & $\mathbf{2}$ & $\mathbf{3}$ \\
\hline 1- Disciplinary Structure & - & - & - \\
\hline 2- Support & $0.71\left(^{* *}\right)$ & - & - \\
\hline 3 -Victimization & 0.02 & $-0.28\left(^{\star *}\right)$ & - \\
\hline
\end{tabular}

Note: $p<.05 .{ }^{* *} p<.01$.

Source: Data from the present study (2017). 
http://dx.doi.org/10.5902/1984686X53606

Because there were relations between support, disciplinary structure, and victimization, the data were further examined to see other relations between the variables.

\section{Structural Equation Modeling}

Five models were tested to examine the relationship between all the variables (see table 5). The final model was selected by the standards defined in the analyses plan and was created with the latent constructs of disciplinary structure and support were added as predictors for victimization, with age and gender as control variables.

Table 5 -Summary of model adjustments

\begin{tabular}{c|c|c|c|c|c}
\hline MODEL & X2 & GL & CFI & RMSEA & SRMR \\
\hline $\begin{array}{c}\text { 1) Disciplinary Structure } \\
\text { (7 items) and Support (8 items) }\end{array}$ & 128.507 & 89 & 0.903 & 0.062 & 0.072 \\
\hline $\begin{array}{c}\text { 2) Disciplinary Structure } \\
\text { (3 items) and Support (7 items) }\end{array}$ & 42.057 & 34 & 0.976 & 0.045 & 0.046 \\
\hline $\begin{array}{c}\text { 3) Victimization } \\
\text { (4 items) }\end{array}$ & 2.316 & 2 & 0.998 & 0.037 & 0.019 \\
\hline $\begin{array}{c}\text { 4) Disciplinary Structure } \\
\text { (3 items), Support (4 items) } \\
\text { and Victimization (4 items) }\end{array}$ & 63.931 & 57 & 0.982 & 0.032 & 0.054 \\
\hline $\begin{array}{c}\text { 5) Disciplinary Structure and Support as } \\
\text { predictors for victimization }\end{array}$ & $62, .17$ & 57 & 0.985 & 0.030 & 0.054 \\
\hline
\end{tabular}

Source: Data from the present study (2017).

The disciplinary structure was composed of items DC3, DC6 E DC7. Support was composed of items SP1, SP2, SP4 e SP8, and victimization by VIT2, VIT3, VIT4, VIT6. The other items were removed because they did not meet the statistical criteria of the study.

The model had a good fit $(X 2(57)=62.817, p>.05, C F I=.985, \quad R M S E A=.030$, $\mathrm{SRMR}=.054)$. The final model is represented in Figure 2, with only the significant associations presented. 
http://dx.doi.org/10.5902/1984686X53606

Figure 2 - Final model

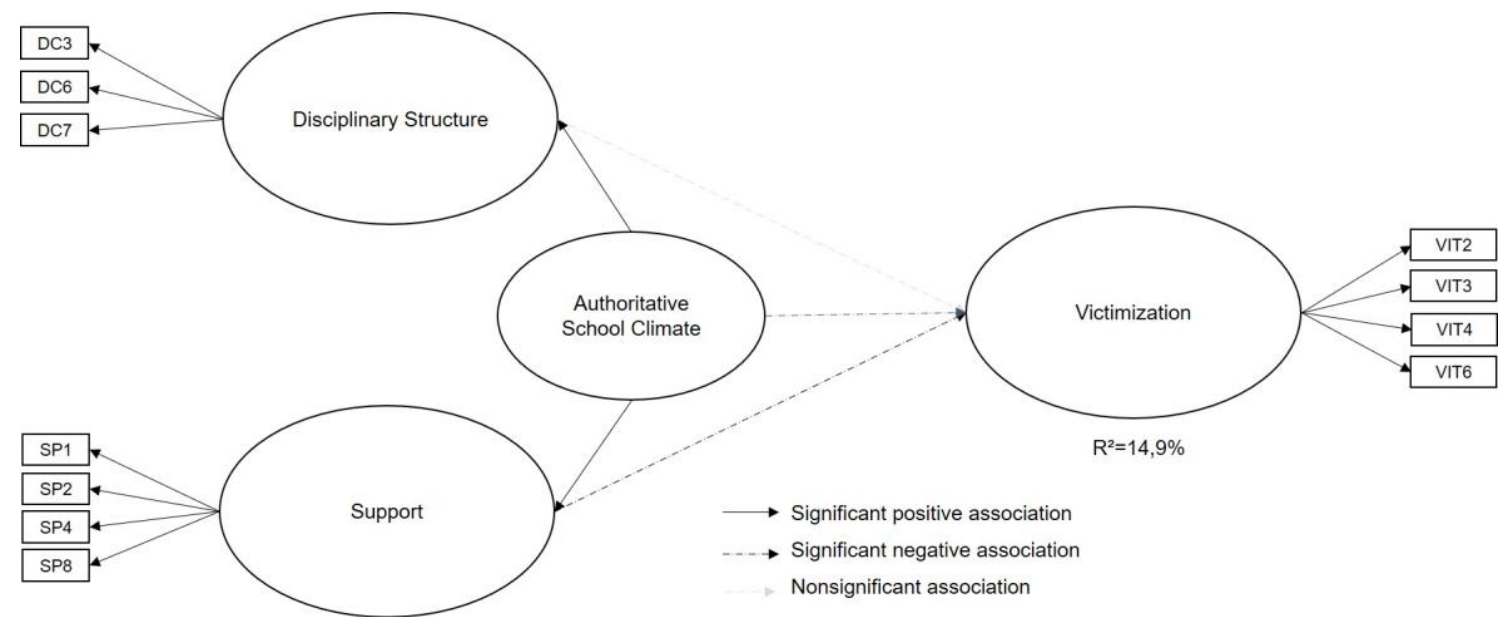

Source: Figure developed by the authors (2017).

The disciplinary structure was positively associated with support $(r=.73, p<.01)$ and age $(r=.29, p<.05)$. Support was a significant negative predictor for victimization $(\beta=-.68$, $p<.05$ S.E.=.27). No other significant associations were found.

\section{Discussion}

The study's main objective was to evaluate the associations between authoritative school climate and peer victimization through students with ID perceptions. Other objectives involved the evaluation of the use of scales accessible for people with ID, above and beyond age and gender differences.

Results indicate positive process for part of disciplinary structure, support and victimization. Beyond the parameters adopted in the paper, by comparing the results with data from other studies with samples without ID, the Cronbach's Alpha for support (.80), although not with all items of the scale, was higher when compared with population without ID - .77 (Cunha et al., 2019;). In addition, factor loads of the study above presented variation between .25-.69, and in the present study the variation was between .65-.84; values that are similar to the original studies of the scale .63-.87 (Cornell, 2017).

For victimization, even with only part of the items of the scale, the Cronbach's Alpha in the study - .82 - was close to one of the author's studies (CUNHA, 2012), .81. Regarding factor loads, in the reference study they vary between .60-.81 and in the present study they were .62-.82.

Therefore, beyond statistical fit adopted in this research, those dimensions presented values close to the studies with the population without ID, indicating relatively trustworthy 
measures. However, for disciplinary structure, direct and relational aggression were not obtained acceptable models or other associations, indicating problems in the adaptation process or lack of relations between the variables in the sample.

Future studies could conduct adjustments in the items and dimensions that presented a lack of statistical adjustment in the present research and, in case of valid and trustworthy measures, the analyses of measurement invariance between groups of people with and without ID. Still, the results obtained in this study are encouraging and present some points considered reliable in the process of a universal design instrument for educational environments regarding school climate and peer victimization. Other limitation in the present study was a large range between student's age. As seen in method section, the participants range in age between 12 and 63 years old, what can represent a large source of variability and experiences regarding school violence. This could be addressed in upcoming studies, identifying specific ways about the changes in peer victimization with students with ID across their lifespan. Besides, the differences seen in age indicate that for this students schools could represent their main source of relationships, and that even in adult life they are still limited to school activities, instead of been encouraged in a professional life or towards other social spaces.

Evaluating the school climate influence on peer victimization, support was perceived as a negative predictor for victimization, as noted in research with the population without ID and that was not attending special schools (CORNELL, 2015). Therefore, for students with a higher perception of school as an environment that is welcoming and where they can seek help in case of need, there were fewer reports of victimization associated. As reported in the results section, this type of effect did not change regarding age or gender differences. This result indicates that overall school staff is an important protective factor for school violence and that professionals should pay special attention in overall educational practices and at the quality of relations into school environments. Therefore, seems necessary that special school's curriculum includes systematic practices that enhance school climate, provides not only physical and educational, but also emotional support, as well as foster positive attitudes between students of all ages.

Developing research methods that are cognitively accessible to all follows a universal design perspective and the promotion of human rights. In this path are many challenges, still, research presents evidence that this is a possible and necessary process to social inclusion in many social spheres. This type of effort could lead to better research practices, 
that instead of excluding people with ID from future larger studies, planned their inclusion since the creation of measures and data collection. This level of change requires also an advance into researchers' own conceptions about data collection and what means an investigation who provides information about the real people from the real world.

Beyond social inclusion of society portions who are systematically excluded through human history, this process also helps fill the gaps in scientific knowledge, such as the association between school climate perception and peer victimization under people with ID reports.

\section{References}

ALDRIDGE, J. M.; MCCHESNEY, K. The relationships between school climate and adolescent mental health and wellbeing: A systematic literature review. International Journal of Educational Research, v. 88, p. 121-145, 2018.

ALEXANDER, Mandi Moody. et al. Effects of Homophobic versus Nonhomophobic Victimization on School Commitment and the Moderating Effect of Teacher Attitudes in Brazilian Public Schools. Journal of LGBT Youth, v. 8, n. 4, p. 289-308, october. 2011.

ALMEIDA, Bruna Rocha de; BARBOSA, Altemir José Gonçalves. Psicologia Positiva e deficiência intelectual: Análise da produção científica. Revista CES Psicología, v. 7, n. 2, p. 44-58, july 2014.

ALVES, Ana Paula Ribeiro; SILVA, Nilson Rogério. What the people with intellectual disability think about their participation in the work from two case studies. Revista Brasileira de Educacao Especial, v. 26, n. 1, p. 109-124, january 2020.

AMARAL, Hellen Tsuruda. Clima Escolar Autoritativo e vitimização entre pares em estudantes com deficiência intelectual. 2018. 98 f. Dissertação (Mestrado em Educação), Universidade Federal do Paraná, 2018.

AMARAL, Hellen Tsuruda; CUNHA, Josafá Moreira da; SANTO, Jonathan Bruce. Authoritative school climate and peer victimization among Brazilian students. Psico, v. 50, n. 1, p. e29275, p.1-8, maio. 2019.

ARAÚJO, Cássia Marta Felix de; COUTINHO, Diógenes José Gusmão. Violência escolar uma revisão sistemática de literatura entre 2009 e 2019. Revista Ibero-Americana de Humanidades, Ciências e Educação, v. 6, n. 1, p. 1-16, 31 janeiro 2020.

BAUMRIND, Diana. Effects of Authoritative Parental Control on Child Behavior. Child Development, v. 37, n. 4, p. 887, december 1966.

BEAR, George ; YANG, Chunyan; PASIPANODYA, Elizabeth. Assessing School Climate: Validation of a Brief Measure of the Perceptions of Parents. Journal of

Psychoeducational Assessment, v. 33, n. 2, p. 115-129, april 2015. 
BERG, Juliette. ; CORNELL, Dewey. Authoritative school climate, aggression toward teachers, and teacher distress in middle school. School Psychology Quarterly, v. 31, n. 1, p. 122-139, january 2016.

BERKOWITZ, R. et al. A Research Synthesis of the Associations Between Socioeconomic Background, Inequality, School Climate, and Academic Achievement. Review of Educational Research, v. 87, n. 2, p. 425-469, 1 abr. 2017.

BRASIL. Lei n.13146, de 6 de julho de 2015. Dispõe sobre a Lei Brasileira de Inclusão da Pessoa com Deficiência. Brasília, 2015. Disponível em:

http://www.planalto.gov.br/ccivil_03/_Ato2015-2018/2015/Lei/L13146.htm . Acesso em: 27 ago. 2020.

BREDEMEIER, Juliana et al. The World Health Organization Quality of Life instrument for people with intellectual and physical disabilities (WHOQOL-Dis): Evidence of validity of the Brazilian version. BMC Public Health, v. 14, n. 1, p. 1-12, maio 2014.

BOCK, G. L. K.; GESSER, M.; NUERNBERG, A. H. Desenho Universal para a aprendizagem: a Produção Científica no Período de 2011 a 2016Revista Brasileira de Educacao Especial. Associacao Brasileira de Pesquisadores em Educação Especial, 2018. Disponível em: http://dx.doi.org/10.1590/S1413-65382418000100011. Acesso em: 25 jan. 2021

BOUERI, lasmin Zanchi; ZUTIAO, Patrícia; ALMEIDA, Maria Amelia. Caderno de Orientações para aplicação WHOQOL - BREF-ID-ADAPTADO. Manual não publicado, 2015.

CANTORANI, José Roberto Herrera; PILATTI, Luiz Alberto ; GUTIERREZ, Gustavo Luis. Análise das versões do instrumento whoqol-dis frente aos aspectos que motivaram sua criação: Participação e autonomia. Revista Brasileira de Educacao Especial, v. 21, n. 4, p. 407-426, dezembro 2015.

COELHO, Maria Teresa Barros Falcão. Bullying escolar: revisão sistemática da literatura do período de 2009 a 2014. Revista. Psicopedagogia, v. 33, n. 102, p. 319-330, janeiro 2016.

COHEN, Jonathan. et al. School Climate: Research, Policy, Practice, and Teacher Education. Teachers College Record, v. 111, n. 1, p. 180-213, january 2009.

CONSELHO FEDERAL DE PSICOLOGIA. Construção, adaptação e validação de instrumento para pessoas com deficiência. Brasília, DF, 2013. Disponível em https://transparencia.cfp.org.br/legislacao/nota-tecnica-construcao-adaptacao-e-validacaode-instrumentos-para-pessoas-com-deficiencia/. Acesso em 11 agosto 2020.

CORCINO, Julio Rodrigues Mota Júnior; CUNHA, Josafá Moreira da. As Tecnologias de Informação e Comunicação (TIC) como ferramenta em pesquisas acadêmicas: Análise do software KoBoToolbox. Revista Brasileira de Iniciação Científica, v. 4, n. 9, p. 13-21, dezembro 2017. 
CORNELL, Dewey. The Authoritative School Climate Survey and The School Climate Bullying Survey : Research Summary. 2015. Disponível em:

https://curry.virginia.edu/sites/default/files/uploads/resourceLibrary/Authoritative_School_C limate_Survey_Research_Summary_1-31-16.pdf. Acesso em: 26 agosto de 2020.

CORNELL, Dewey.; HUANG, Francis. Authoritative School Climate and High School Student Risk Behavior: A Cross-sectional Multi-level Analysis of Student Self-Reports. Journal of Youth and Adolescence, v. 45, n. 11, p. 2246-2259, november 2016.

CORNELL, Dewey; SHUKLA, Kathan; KONOLD, Timothy. Peer Victimization and Authoritative School Climate: A Multilevel Approach. Journal of Educational Psychology, v. 107, n. 4, p. 1186-1201, november 2015.

CRONBACH, Lee Joseph. Coefficient alpha and the internal structure of tests.

Psychometrika, v. 16, n. 3, p. 297-334, september 1951.

CUNHA, Josafá Moreira da. O papel moderador de docentes na associação entre violência escolar e ajustamento acadêmico. 2012. 167 f. Tese (Doutorado em Educação), Universidade Federal do Paraná, 2012.

CUNHA, Josafá Moreira da; AMARAL, Hellen Tsurida; MACEDO, Ana Moreira Borges de. Clima Escolar Autoritativo: Adaptação e Evidências de Validade entre Estudantes Brasileiros. Psicologia Argumento, v. 37, n. 96, p. 273, dezembro. 2019.

CUNHA, Josafá Moreira da; WEBER, Lidia Natalia Dobrianskyj.; STEINER, Pedro. Escala de Vitimização e Agressão Entre Pares (EVAP). In: Pesquisando a família: Instrumentos para coleta e análise de dados. Curitiba: Juruá, 2009 p. 103-114.

EMERICH, Deisy Ribas; ALCKMIN-CARVALHO, Felipe; MELO, Márcia Helena Silva. Rejeição e vitimização por pares em crianças com Deficiência Intelectual e Transtorno do Espectro Autista. Revista Educação Especial, v. 30, n. 58, maio 2017. Disponível em: https://periodicos.ufsm.br/educacaoespecial/article/view/22217. Acesso em: 27 agosto 2020.

FISHER, B. W. et al. Students' Feelings of Safety, Exposure to Violence and Victimization, and Authoritative School Climate. American Journal of Criminal Justice, v. 43, n. 1, p. 6-25, 1 mar. 2018.

GEORGE, Darren; MALLERY, Paul. SPSS for Windows step by step: A simple guide and reference. 11.0 update. 40 edition ed. Boston: Allyn \& Bacon, 2003.

HOLST, Bruna. et al. Brazilian cross-cultural adaptation and content validity of the Delaware School Climate Survey-Student (DSCS-S). Relieve, v. 22, n. 2, p. 1-11, july 2016.

HONG, Jun Song; ESPELAGE, Dorothy. A review of research on bullying and peer victimization in school: An ecological system analysis. Aggression and Violent Behavior, v. 17 , n. 4 , p. 311-322, july 2012.

JOSEPH, Stephen; STOCKTON, Hannah. The multidimensional peer victimization scale: A systematic review. Aggression and Violent Behavior, v.42, p.96-114, september 2018. 
KLINE, Rex. Principles and Practice of Structural Equation Modeling. 4. ed. New York: The Guilford Press, 2011.

KONOLD, Timothy. et al. Racial/Ethnic Differences in Perceptions of School Climate and Its Association with Student Engagement and Peer Aggression. Journal of Youth and Adolescence, v. 46, n. 6, p. 1289-1303, june 2017.

KONOLD, Timothy; CORNELL, Dewey. Measurement and structural relations of an authoritative school climate model: A multi-level latent variable investigation. Journal of School Psychology, v. 53, n. 6, p. 447-461, december 2015.

KRETSCHMER, Tina. What Explains Correlates of Peer Victimization? A Systematic Review of Mediating Factors. Adolescent Research Review, v. 1, n. 4, p. 341-356, july 2016.

LA SALLE, Tamika. et al. An examination of school climate, victimization, and mental health problems among middle school students self-identifying with emotional and behavioral disorders. Behavioral Disorders, v. 43, n. 3, p. 383-392, may 2018.

LÅFTMAN, Sara Brolin; ÖSTBERG, Viveca; MODIN, Bitte. School climate and exposure to bullying: a multilevel study. School Effectiveness and School Improvement, v. 28, n. 1, p. 153-164, january 2017.

LENZ, A. S.; ROCHA, L.; ARAS, Y. Measuring School Climate: A Systematic Review of Initial Development and Validation Studies. International Journal for the Advancement of Counselling, p. 1-15, 16 out. 2020.

LEÓNA, J. A.; LEÓN-LÓPEZ, A. Reading performance in adults with intellectual and developmental disability (IDD) when they read different kinds of texts. Psychology in Russia: State of the Art, v. 12, n. 4, p. 148-158, 2019.

LOVEMAN, Mara; MUNIZ, Jeronimo; BAILEY, Stanley. Brazil in black and white? Race categories, the census, and the study of inequality. Ethnic and Racial Studies, v. 35, n. 8, p. 1466-1483, august. 2012.

MAÏANO, Christophe. et al. Prevalence and correlates of bullying perpetration and victimization among school-aged youth with intellectual disabilities: A systematic review. Research in Developmental Disabilities, v. 49-50, p. 181-195, february 2016.

MAXWELL, Sophie. et al. The impact of school climate and school identification on academic achievement: Multilevel modeling with student and teacher data. Frontiers in Psychology, v. 8, december 2017. Disponível em:

https://www.sciencedirect.com/science/article/pii/S1359178917302732?via\%3Dihub. Acesso em: 20 agosto 2020.

MONTEIRO, Solange Aparecida de Souza; RIBEIRO, Paulo Rennes Marçal. O lugar das crianças com deficiências na educação infantil e políticas de inclusão na educação brasileira. Revista Ibero-Americana de Estudos em Educação, v. 14, n. esp1, p. 730745, abril 2019. 
MOYANO, N.; SÁNCHEZ-FUENTES, M. DEL M. Homophobic bullying at schools: A systematic review of research, prevalence, school-related predictors and consequences Aggression and Violent Behavior. Elsevier Ltd, 1 jul. 2020.

MUSIL, Bojan et al. Aggression in school and family contexts among youngsters with special needs: Qualitative and quantitative evidence from the TranSpace project. Children and Youth Services Review, v. 44, p. 46-55, september 2014.

MUTHÉN, Linda; MUTHÉN, Bengt. Mplus user's guide. Vol. 6. Los Angeles: CA Muthén \& Muthén, 2010.

OLIVEIRA, Cassandra Melo et al. Desenho universal e avaliação psicológica na perspectiva dos direitos humanos. Avaliação Psicológica, v. 12, n. 3, p. 421-428, março 2013.

OLIVEIRA, C. M.; NUNES, C. H. S. DA S. Modelo de Testagem Universal Aplicado à Área da Avaliação Psicológica. Psicologia: Ciência e Profissão, v. 38, n. spe, p. 98-107, 2018.

OLIVEIRA, Paula Approbato de. et al. Intellectual deficits in Brazilian victimized children and adolescents: A psychosocial problem? Child Abuse and Neglect, v. 36, n. 7-8, p. 608-610, july 2012.

PARANÁ. Secretaria de Estado da Educação. Departamento de Educação Especial e Inclusão Educacional. Política Estadual de Educação Especial na Perspectiva da Inclusão. Curitiba, PR, 2009. Disponível em:

http://www.nre.seed.pr.gov.br/londrina/arquivos/File/1politicasemanapedfev2010.pdf. Acesso em: 15 outubro 2019.

PARANÁ. Secretaria de Estado da Educação. Departamento de Educação Especial e Inclusão Educacional. Todos Iguais pela Educação. Curitiba, PR, 2013. Disponível em: http://www.legislacao.pr.gov.br/legislacao/pesquisarAto.do?action=exibir\&codAto=99967\& ndice $=1$ \&totalRegistros=1. Acesso em: 23 outubro 2019 .

PEDRO, Kris. de et al. Examining the Relationship Between School Climate and Peer Victimization Among Students in Military-Connected Public Schools. Violence and Victims, v. 31, n. 4, p. 751-766, january 2016.

PINA, Andréia Soares; ARAUJO, Doracina Aparecida de Castro. Violência contra crianças com deficiência. Interfaces da educação, v. 12, n. 12, 2014. Disponível em: https://periodicosonline.uems.br/index.php/interfaces/article/view/512. Acesso em 15 julho 2020.

RAMSEY, Christine et al. School climate: perceptual differences between students, parents, and school staff. School Effectiveness and School Improvement, v. 27, n. 4, p. 629-641, october 2016.

SANTOS, Teresa Cristina Coelho; MARTINS, Lúcia de Araújo Ramos. Práticas de professores frente ao aluno com deficiência intelectual em classe regular. Revista Brasileira de Educacao Especial, v. 21, n. 3, p. 395-408, julho 2015. 
SCHMIDT, Silke et al. Self and proxy rating of quality of life in adults with intellectual disabilities: Results from the DISQOL study. Research in Developmental Disabilities, v. 31, n. 5, p. 1015-1026, september 2010.

STOCKARD, Jean; MAYBERRY, Maralee. Effective Educational Environments. 1. ed. Thousand Oaks: Corwin, 1992.

THAPA, Amrit. et al. A Review of School Climate Research. Review of Educational Research, v. 83, n. 3, p. 357-385, september 2013.

THOMPSON, Sandra; JOHNSTONE, Christopher; THURLOW, Martha. Universal design applied to large scale assessments. National Center on Educational Outcomes Council of Chief State School Officers (CCSSO), n. 44 p. 1-26, june 2002.

TODOS PELA EDUCAÇÃO. Anuário brasileiro da educação básica 2017. São Paulo, SP, 2017. 90p. Disponível em:

https://www.todospelaeducacao.org.br/biblioteca/1567/anuario-brasileiro-da-educacaobasica-2017. Acesso em: 15 setembro 2018.

VINHA, Telma Pileggi. et al. O clima escolar e a convivência respeitosa nas instituições educativas. Estudos em Avaliação Educacional, v. 27, n. 64, p. 96, maio 2016.

WEHMEYER, Michael. The Oxford Handbook of Positive Psychology and Disability. 1. ed. Oxford: Oxford University Press, 2013.

WIENER, Judith. Do peer relationships foster behavioral adjustment in children with learning disabilities? Learning Disability Quarterly, v.27 n.1, 2004. Disponível em: http://journals.sagepub.com/doi/10.2307/1593629. Acesso em: 26 ago. 2020

WILLIFORD, Anne. et al. Associations between peer victimization and school climate: The impact of form and the moderating role of gender. Psychology in the Schools, v. 56, n. 8, p. 1301-1317, july 2019. 